Mohamed Naguib MB в CH M SC FFARCS1, C.E. Famewo MB FRCPC, Afaf Absood BS MS

\title{
Pharmacokinetics of meperidine in spinal anaesthesia
}

We recently reported the use of intrathecal

Five male patients undergoing haemorrhoidectomy received intrathecal meperidine $1 \mathrm{mg} \cdot \mathrm{kg}^{-1}$ as the sole anaesthetic agent. Plasma concentration-time profiles were investigated. The peak plasma concentration of meperidine was $175 \pm 78.8 \mathrm{ng} \cdot \mathrm{ml}^{-1}$ (mean $\left.\pm S D\right)$ and this occurred 90 minutes after intrathecal injection. The plasma concentrations generally were lower than those necessary for systemic analgesic effects. The terminal elimination half life of meperidine $\left(t_{\frac{1}{2}} \beta\right)$ in the plasmo was 198 minutes.

Intrathecal meperidine produced good surgical anaesthesia in all patients studied. The mean duration of sensory and motor block was $77 \pm 18.8$ and $47 \pm 7.4$ minutes respectively. Four patients did not require any analgesic supplement during the postoperative period. No parient developed clinically evident respiratory depression or neurological sequlae.

The pharmacokinetic data suggests that intrathecal meperidine provides prolonged postoperative analgesia through a regional effect on opioid receptors in the spinal cord.

Intrathecal opioid administration has received less clinical investigation than the epidural route. The intrathecal route has been used to provide analgesia after surgery and for the control of pain in labour and myocardial infarction. ${ }^{1-6}$

\section{Key words}

ANAESTHETIC TECHNIQUES: spinal anaesthesia; ANAESTHETIC: local, meperidine; PHARMACOKINETICS: kinetics; PAIN: postoperative.

From the Departments of Anesthesiology and Clinical Pharmacology (A. Absood), King Faisal University, Saudi Arabia.

Address correspondence to: Dr. M. Naguib, Department of Anesthesiology, King Faisal University, King Fahd Hospital, P.O. Box 2208, Al-Khobar, Saudi Arabia 31952. meperidine as the sole agent for spinal anaesthesia. ${ }^{7}$ Since there is no quantitative information available for intrathecal meperidine in doses used for spinal anaesthesia, we performed a study of the kinetics of intrathecal meperidine when used in a dose of $1 \mathrm{mg} \cdot \mathrm{kg}^{-1}$ for spinal anaesthesia.

\section{Methods}

Five male patients of ASA physical status I or II presenting for haemorrhoidectomy were studied. The mean age was $38 \pm 15$ years, and the mean weight was $61.6 \pm 6.5 \mathrm{~kg}$ ( $\pm \mathrm{SD}$ ). The protocol was approved by the hospital review committee and informed consent was obtained from the patients. No premedication was given.

The protocol described in the original report by Famewo and Naguib ${ }^{7}$ was employed in this study. In summary, subarachnoid puncture was performed with the patient in the sitting position, using a 22-gauge spinal needle at the lumbar vertebral level of $L 3 / 4$ or $L 4 / 5$. Preservative-free meperidine in a dose of $1 \mathrm{mg} \cdot \mathrm{kg}^{-1}$ was injected intrathecally using the undiluted concentration of $50 \mathrm{mg} \cdot \mathrm{ml}^{-1}$. Intraoperative monitoring included ECG, blood pressure, tidal volume, end-tidal $\mathrm{CO}_{2}$ and arterial blood gases.

The onset and duration of sensory block as determined by the pinprick method were noted. The onset and duration of motor weakness of the lower extremities were also noted.

Postoperatively, patients were monitored closely. Blood pressure, heart rate, and respiratory rate were recorded at hourly intervals, while arterial blood gases were determined at four hourly intervals for the first 24 hours after the end of surgery. One of the authors was always available for immediate assessment of patients should there by any complaint or problem, and any side effects were noted. 


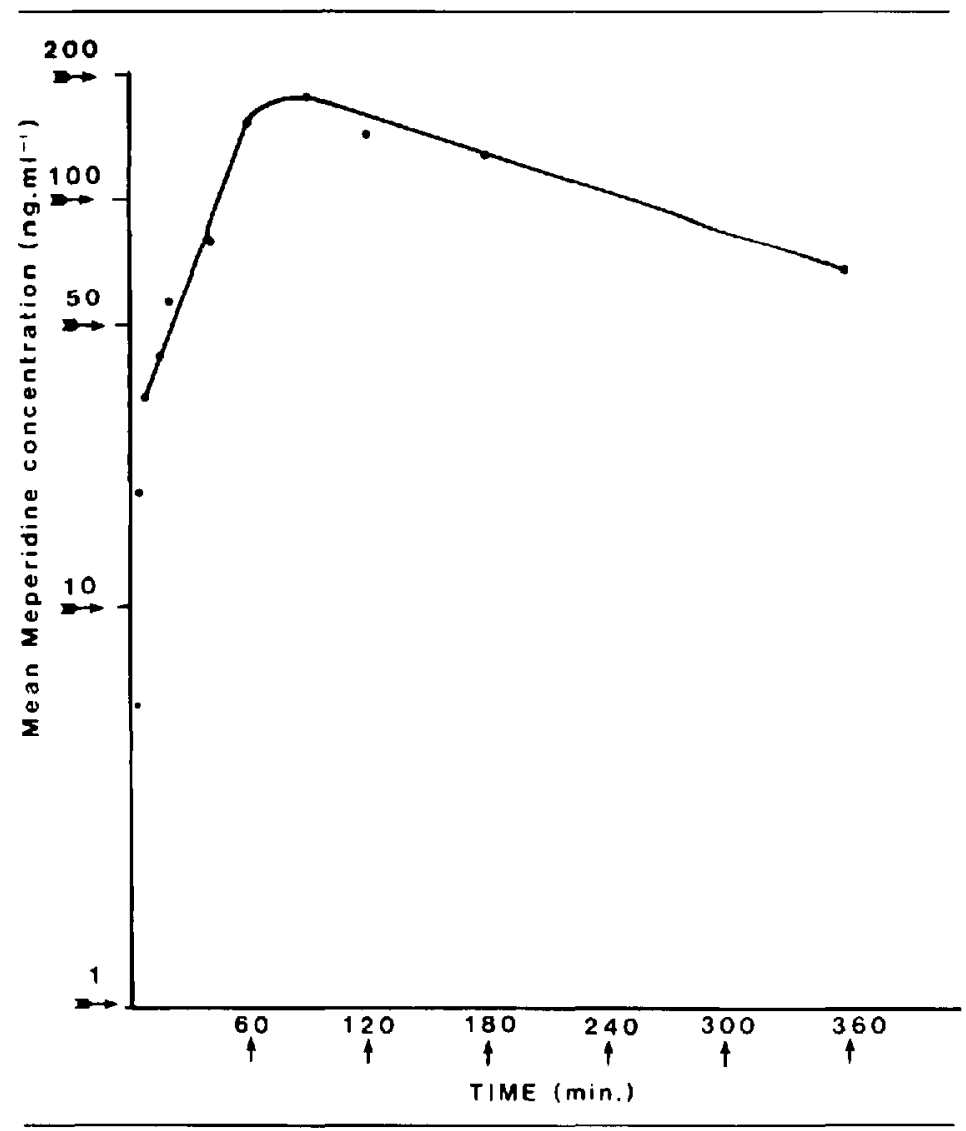

FIGURE Mean venous plasma concentrations of meperidine.

\section{Postoperative pain assessment}

The severity of pain was evaluated using a linear analogue pain scale from $0-10$. The scale was explained to the patient, " 0 " corresponding to "no pain" and "10" corresponding to "severe unbearable pain." Meperidine $0.8 \mathrm{mg} \cdot \mathrm{kg}^{-1} \mathrm{IM}$ was prescribed if the pain score exceeded three.

A neurological examination was performed on each patient before discharge from the hospital to exclude any neurological deficit.

Meperidine determination and pharmacokinetics An indwelling venous cannula was used to sample blood from an antecubital vein in the contralateral arm to that used for intravenous fluid administration. Venous blood was collected from each patient into heparinized tubes at 2, 5, 10,20,40,60, 90, 120 and 180 minutes after intrathecal injection of meperidine. In two patients blood sampling was extended to 360 minutes after meperidine injection.

Plasma meperidine concentrations were measured using gas chromatography as described by Mather and Tucker. ${ }^{8}$ This is a highly sensitive method utilizing an internal standard for the determination of meperidine in plasma. In addition, there is no potential for drug loss by volatilization since no evaporation of the solvent is required by this method.

A drug concentration-time curve was constructed for the mean data (Figure) and the following were determined: maximum concentration $\left(\mathrm{C}_{\max }\right)$, time to $C p_{\max }\left(t_{\max }\right)$, and terminal elimination half life $\left(t_{1} \beta\right)$. 
TABLE I Venous plasma concentration of meperidine $\left(n \mathrm{ng} \cdot \mathrm{ml}^{-1}\right)$ following intrathecal administration of meperidine $1 \mathrm{mg} \cdot \mathrm{kg}^{-1}$

\begin{tabular}{|c|c|c|c|c|c|c|}
\hline \multirow{2}{*}{$\begin{array}{l}\text { Time } \\
(\min )\end{array}$} & \multicolumn{5}{|c|}{ Patient number } & \multirow[b]{2}{*}{$M e a n \pm S D$} \\
\hline & $l$ & 2 & 3 & 4 & 5 & \\
\hline 0 & 0 & 0 & 0 & 0 & 0 & $0 \pm 0$ \\
\hline 2 & 0 & 0 & 0 & 27 & 2.4 & $5.8 \pm 10.6$ \\
\hline 5 & 13 & 6 & 34.5 & 41.6 & 3.3 & $19.7 \pm 15.4$ \\
\hline 10 & 22.5 & 9.3 & 66.5 & 64 & 7 & $33.8 \pm 26 . t$ \\
\hline 15 & 41 & 17 & 67 & 71 & 10.5 & $41.3 \pm 24.8$ \\
\hline 20 & 59 & 29 & 85.5 & 96.5 & 18 & $57.6 \pm 30.5$ \\
\hline 40 & 64 & 58 & 89 & 137 & 58.5 & $81.3 \pm 30$ \\
\hline 60 & 100 & 108.5 & 133 & 359 & 72 & $154.5 \pm 104$ \\
\hline 90 & 145 & 152 & 166 & 324 & 89 & $175.2 \pm 78.8$ \\
\hline 120 & 107 & 147 & 105 & 270.6 & 74.5 & $140.8 \pm 68.8$ \\
\hline 180 & 101 & 146 & 85.5 & 246 & 65 & $128.7 \pm 64.4$ \\
\hline 360 & 74 & - & - & - & 59 & $66.5 \pm 7.5$ \\
\hline
\end{tabular}

\section{Results}

Meperidine was rapidly absorbed, appearing in the plasma of two patients in the first sample taken at two minutes following intrathecal administration of meperidine. In the second sample taken at five minutes, meperidine was detectable in the plasma of all patients with a mean concentration of 5.8 $\mathrm{ng} \cdot \mathrm{ml}^{-1}$.

There was a four-fold variation in peak plasma concentration $\left(89-359 \mathrm{ng} \cdot \mathrm{ml}^{-1}\right)$. The time to peak plasma concentration $\left(t_{\max }\right)$ in four patients was 90 minutes. The terminal half-life $\left(\varphi_{i} \beta\right)$ of meperidine was 198 minutes. The details of individual patients and kinetics parameters are presented in Tables I and II.

\section{Sensory and motor block}

Meperidine produced surgical anaesthesia in all patients studied. The mean time of onset of sensory and motor block was $5.8 \pm 2.1$ and $6.2 \pm 2.5$ minutes respectively. The level of sensory block

TABLE II Kinetic parameters after intrathecal administration of meperidine I mg $\mathrm{kg}^{-1}$ (Calculations derived from a onecomparment model)*

\begin{tabular}{|c|c|c|c|}
\hline $\begin{array}{l}\text { Mean Dose } \\
\text { (mg) }\end{array}$ & $\begin{array}{l}\text { Mean } C p_{\max } \\
\left(n g \cdot m l^{-1}\right)\end{array}$ & $\begin{array}{l}l_{\max } \\
(\min )\end{array}$ & $\begin{array}{l}{ }_{1}^{4} \beta \\
(\text { min })\end{array}$ \\
\hline 61.6 & 175 & 90 & 198 \\
\hline
\end{tabular}

*The terminal elimination half life $\left(t_{4} \beta\right)$ was calculated from the formula $4 \beta=(0.693 / \beta)$ where $\beta$ is the elimination rate constant obtained by a monoexponential fit to the mean data. yaried between $\mathrm{T}-7$ and $\mathrm{T}-12$ with a mean T-9. The mean duration of sensory and motor block was $77 \pm 18.8$ and $47 \pm 7.4$ minutes respectively. There were no neurological sequelae.

\section{Postoperative analgesia and side effects}

Four of the five patients had pain scores in the range of 0 to 2 and did not require any analgesic supplement during the four day postoperative period. Only one patient had a pain score of four and required one intramuscular injection of meperidine on the second postoperative day. All patients were ambulant early in the postoperative period.

No patient developed respiratory depression, urinary retention, nausea or vomiting.

One patient had hypotension. The systolic blood pressure decreased by 30 per cent of the pre-block value 25 minutes after intrathecal injection of meperidine. The hypotension was treated with ephedrine $10 \mathrm{mg}$ intravenously. Another patient developed bradycardia, 50 minutes after intrathecal injection of meperidine which responded to $0.6 \mathrm{mg}$ atropine IV. Three patients experienced mild pruritus on the face, especially the nose, $20-25$ minutes after intrathecal administration of meperidine, but this disappeared spontaneously within 10-15 minutes. These side effects were observed in three of the five patients studied.

\section{Discussion}

Our results indicate that vascular absorption of meperidine is rapid after intrathecal administration. 
Meperidine is a lipophilic narcotic which after subarachnoid injection will rapidly penetrate the spinal cord receptors and non-specific binding sites, producing a high local drug level in the spinal cord. For a lipophilic drug like meperidine, systemic uptake occurs readily. ${ }^{9,10}$ The rapid uptake may be related to rapid passage across the arachnoid granulations into venous and lymphatic clearance channels. ${ }^{11}$ This could explain the early detection of meperidine in the plasma. Absorption by the arachnoid villi located in the spinal root sleeves ${ }^{12}$ may provide an additional route for drug removal.

Rapid systemic uptake and redistribution of meperidine was noted after both epidural and intramuscular administration. ${ }^{13}$ Boreus et al..$^{14}$ reported that meperidine appeared within less than 18 minutes in the CSF after intramuscular injection.

The peak plasma concentration of meperidine seen in this study occurred at 90 minutes. Following epidural administration of $30 \mathrm{mg}$ meperidine, Tamsen et al. ${ }^{15}$ observed that the peak plasma concentration occurred at 15 minutes. This difference may be related to the rapid absorption of meperidine by the venous plexus in the epidural space. Mather et al. ${ }^{16}$ observed considerable variability in the plasma concentration-time profile following the intramuscular administration of meperidine.

The plasma concentrations of meperidine obtained in this study were below $400-500 \mathrm{ng} \cdot \mathrm{ml}^{-1}$, which is the reported minimum concentration necessary for systemic analgesic effect. ${ }^{17,18}$ Cousins et al..$^{19}$ noted complete pain relief for up to 48 hours after subarachnoid administration of $10-30 \mathrm{mg}$ meperidine to patients with cancer pain; however, plasma levels were not measured. Prolonged postoperative pain relief as observed in this study may be related to a high regional concentration of meperidine in the CSF, sufficient to provide analgesia but inadequate for motor blockade or complete sensory loss. Characteristically, postoperative pain relief was not associated with any regional sensory or motor impairment

Concomitant CSF and plasma determinations would have provided more information regarding the changes in the $\mathrm{CSF} /$ plasma concentration ratio, but this was considered ethically unjustified. Glynn et al.$^{9}$ reported that analgesia produced by epidural meperidine was related to CSF concentrations in that patients having a high $\mathrm{CSF} /$ blood concentration ratio also had complete analgesia. They also observed a considerable wide range of CSF/blood meperidine concentration ratios $(0.9-330)$. In the same study, Glynn et al. ${ }^{9}$ found that $100 \mathrm{mg}$ meperidine administered epidurally had no local anaesthetic effect. In contrast, successful spinal anaesthesia was obtained with meperidine $1 \mathrm{mg} \cdot \mathrm{kg}^{-1}$ in all patients because spinal nerves in the subarachnoid space are covered only with the thin pia mater, thus they can be easily blocked. Meperidine has local anaesthetic properties in concentrations between two and four per cent. ${ }^{20}$

Respiratory depression was not observed in any patient in this study. Almost all cases of respiratory depression have been with use of intrathecal morphine ${ }^{1,11}$ which exhibits a different kinetic behaviour. A drug with low lipophilicity like morphine is believed to persist at higher concentrations in the CSF for longer than one with high liphophilicity like meperidine. Therefore, any event that causes rostral movement of drug in the CSF could result in respiratory depression. Moore et $a l^{21}$ reported that diamorphine, a lipophilic drug, was removed from CSF more rapidly than morphine. They concluded that the lipophilic opiates may be safer for intrathecal use because of the shorter life of substantial drug concentrations in the mobile CSF phase.

However, close postoperative monitoring is advisable until more is known about the dynamics of CSF flow and the pharmacokinetics of intrathecal meperidine when used as the sole agent for spinal anaesthesia.

In conclusion, intrathecal meperidine in a dose of $1 \mathrm{mg} \cdot \mathrm{kg}^{-1}$ is effective as the sole agent for spinal anaesthesia. The present data indicate that the plasma concentration produced with this technique are less than the reported minimum analgesic concentrations. The prolonged postoperative analgesia produced by intrathecal meperidine appears to be due to an interaction with the opioid receptors in the spinal cord.

\section{Acknowledgements}

The authors wish to thank Engineer Ian Stubbs for his technical assistance and Mr. Emmanuel Lapak for typing the manuscript. 


\section{References}

1 Gjessing J, Tomlin PJ. Postoperative pain control with intrathecal morphine. Anaesthesia 1981; 36: 268-76.

2 Pasqualucci $V$, Moricca $G$, Salinas $P$. Intrathecal morphine for the control of the pain of myocardial infarction. Anaesthesia 1981; 36: 68-9.

3 Baraka A, Noueihid R, Hajj S. Intrathecal injection of morphine for obstetric analgesia. Anesthesiology 1981; 54: 136-40.

4 Bengtsson M, Lofstrom JB, Merits H. Postoperative pain relief with intrathecal morphine after major hip surgery. Regional Anesthesia 1983; 8: 139-43.

5 Kalso E. Effects of intrathecal morphine, injected with bupivacaine, on pain after orthopaedic surgery. Br J Anaesth 1983; 55: 415-21.

6 Paterson GMC, McQuay HJ, Bullingham RES, Moore RA. Intradural morphine and diamorphine. Dose response studies. Anaesthesia 1984; 39: 113-7.

7 Famewo CE, Naguib M. Spinal anaesthesia with meperidine as the sole agent. Can Anaesth Soc J 1985; 32: 553-7.

8 Mather LE, Tucker GT. Meperidine and other basic drugs: general method for their determination in plasma. J Pharm Sci 1974; 63: 306-7.

9 Glynn CJ, Mather LE, Cousins NJ, Graham JR, Wilson $P R$. Peridural meperidine in humans: analgetic response, pharmacokinetics and transmission into CSF. Anesthesiology 1981; 55: 520-6.

10 Husemeyer RP, Cummings AJ, Rosankiewicz JR, Davenport $H T$. A study of pethidine kinetics and analgesia in women in labour following intravenous, intramuscular and epidural administration. $\mathrm{Br}$ J Clin Pharmacol 1982; 13: 171-6.

11 Cousins MJ, Mather LE. Intrathecal and epidural administration of opioids. Anesthesiology 1984; 61: $276-310$.

12 Somjen $G G$. Spinal fluids and ions. Handbook of the spinal cord, Vol. 1, ed. R.A. Davidoff. Marcel Dekker Inc., New York 1983, pp. 329-80.

13 Gustafsson LL, Garle M, Johannisson J, Rane A, Stenport $J$, Walson $P$. Regional epidural analgesia: kinetics of pethidine. Acta Anaesthesiol Scand 1982; Suppl 74: 165-8.

14 Boreus LO, Skoldefors E, Ehrnebo M. Appearance of pethidine and norpethidine in cerebrospinal fluid of man following intramuscular injection of pethidine. Acta Anaesthesiol Scand 1983; 27: 222-5.

15 Tamsen A, Sjostrom S, Hartvig P, Persson P, Gabrielsson J, Paalzow L. CSF and plasma kinetics of morphine and meperidine after epidural administration. Anesthesiology 1983; 59: A 196.

16 Mather LE, Tucker GT, Pflug AE, Lindop MJ, Wilkerson $C$. Meperidine kinetics in man. Intravenous injection in surgical patient and volunteers. Clin Pharmacol Therap 1975; 17: 21-36.

17 Mather LE, Meffin PJ. Clinical pharmacokinetics of pethidine. Clin Pharmacokin 1978; 3: 352-68.

18 Stapleton JV, Austin KL, Mather LE. A pharmacokinetic approach to postoperative pain: continuous infusion of pethidine. Anesth Intensive Care 1979; 7: 25-32.

19 Cousins MJ, Mather LE, Glynn GJ, Wilson PR, Graham JR. Selective spinal analgesia. Lancet 1979; 8: 1141-2.

20 Way $E L$. Studies on the local anaesthetic properties of isonipercaine. J Am Pharm Assoc. 1946; 35: 44-7.

21 Moore A, Bullingham R, McQuay $H$, Allen $M$, Baldwin D. Cole A. Spinal fluid kinetics of morphine and heroin. Clin Pharmacol Ther 1984; 35: $40-5$.

\section{Résumé}

Cinq patients devant subir un hémorroidectomie ont reçu de la méperidine $1 \mathrm{mg} \cdot \mathrm{kg}^{-1}$ intrathécale comme seul agent anesthésique. Les profiles temps-concentration plasmatique ont été investigués. La concentration plasmatique maximale de meperidine était de $175 \pm 78.8$ $n g \cdot m l^{-1}$ (moyenne $\pm S D$ ) et est survenue 90 minutes après l'injection intrathécale. Les concentrations plasmatiques ont généralement été plus basses que celles nécessaires pour l'analgésie systémique. La demie vie de la méperidine $\left(\mathrm{t}_{\frac{1}{2}} \beta\right)$ dans le plasma était de 198 minutes.

$L$ 'injection intrathécale de meperidine a produit une anesthésie chirurgicale de bonne qualité chez tous les patients étudiés. La durée moyenne du bloc sensoriel et moteur était de $77 \pm 18.8$ et $47 \pm 7.4$ (moyenne $\pm S D$ ) minutes respectivement. Quatre patients n' ont pas requis d'analgésie supplémentaire lors de la période post opératoire. Aucun patient n'a développé de dépression respiratoire évidente ou de séquelles neurologiques.

Les données pharmacokinétiques suggèrent que la meperidine intrathécale fournie une analgésie post-opé. ratoire prolongée par l' entremise d' un effet régionale sur les récepteurs opiacés de la moelle épinière. 